\title{
PANDANGAN ABDURRAHMAN WAHID TENTANG RELASI ISLAM DAN NEGARA: PENDEKATAN SOSIO-KULTURAL
}

\author{
Saefur Rochmat \\ Universitas Negeri Yogyakarta \\ Email: rochmat@yahoo.com
}

\section{Abstract}

Abdurrabman Wabid introduces a socio-cultural approach to deal with the issue of the relationship between Islam and state. The approach is a kind of modification to the Fiqh approach advocated by Nabdhatul Ulama (NU) to suit it to the development of modern sciences as well as to understand the latter based on Islamic cosmology. According to him, Islamic identity is Islamic cosmology which views the spirit and the material intermingling in the worldly life. Accordingly Muslim should respond to the issues of modernity based on this Islamic tradition with the hope to direct the modernity discourses. By so doing it will help to mediate the conflict of ideologies based on its belief that "the normative" intermingles with "the particular" and as consequences there is no absolute truth prevailing in this worldly life.

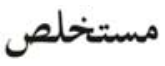

عبد الرحمن وحيد يقدم فجا الاجتماعية والثقافية للتعامل مع مسألة العلاقة بين الإسلام والدولة. النهج هو نوع من التعديل لنهج الفقه نادى هـا فضةالعلماء (NU) لتناسب لتطوير العلوم الحديثة وكذلك لفهم هذا الأخير على أساس علم الكونيات الإسلامية. ووفقا له، و الهوية الإسلامية هي علم الكونيات الإسلامية التي ترى أن الروح والمادة الاختلاط في الحياة الدنيا. وبناء على ذلك مسلم الاستجابة لقضايا الحداثة وبناء على هذا التقليد الإسالامي على أمل لتوجيه الخطابات الحمداثة. بذلك أها سوف تساعد على التوسط في الصراع من الإيديولوجيات القائمة على اعتقادها بأن "المعيارية" يختلط مع "خاصة"و بالتالي ليس هناك عو اقب الحقيقة المطلقة السائدة في هذه الحياة الدنيا. Keywords:: fiqh approach, socio-cultural approach, Islamic cosmology, Islamic tradition, 


\section{A. Pendahuluan}

Berkaitan dengan hubungan Islam dan negara di era modern ada tiga pandangan, yaitu teokratis (Islam sebagai agama dan negara), sekuleris (agama dipisahkan dari negara, seperti di Turki), dan agamis/kultural/fiqih. Dua pandangan pertama bisa disebut dengan pendekatan ideologis dalam hubungan Islam dan negara. Pandangan pertama melihat bentuk negara teokratis sebagai bentuk negara ideal yang harus diperjuangkan, sedangkan pandangan kedua berjuang mewujudkan bentuk negara sekuler sebagai model idealnya. Kedalam pendekatan ideologis dapat ditambahkan kelompok komunis yang mendukung bentuk negara ideal sebagai komunis. Para pendukung pendekatan ideologis menghendaki terjadinya perubahan revolusioner terhadap bentuk negara yang dipandangnya belum ideal. Mereka tidak segan-segan menggunakan kekerasan walaupun dengan mencari justifikasi dari sumber ajarannya masing-masing. ${ }^{1}$ Sedangkan pandangan ketiga dikenal dengan pendekatan fiqih dalam hubungan Islam dengan negara. Mereka memahami Al-Qur'an tidak mengandung "sistem" negara ideal yang harus diperjuangkan secara revolusioner, karena ajaran Islam bisa dijalankan dalam suatu komunitas dibawah kepemimpinan seorang ulama. Baginya Al-Qur'an hanya berisi pesan etis bagi berjalannya sistem pemerintahan yang efektif, dan bila Al-Qur'an menyebut suatu sistem maka hal itu dimaksudkan sebagai suatu contoh bagi aplikasi pesan-pesan etis saja.

Dalam melihat hubungan agama dengan negara, Wahid menggunakan pendekatan fiqih mengikuti Tradisi Walisanga sebagaimana diadvokasi oleh Nahdhatul Ulama (NU), organisasi tempat dia berkecimpung. Berdasarkan pendekatan fiqih, bentuk negara Indonesia dibicarakan oleh berbagai elemen dalam masyarakat dan tidak diputuskan sendiri oleh Muslim walaupun mereka menjadi mayoritas. NU tidak memaksakan bentuk negara Islam karena tidak ada kewajiban agama mendirikan negara Islam. Namun Wahid, kemudian, bersikap kritis terhadap pendekatan fiqih yang dinilainya kurang bersikap kritis terhadap pemerintah, mengingat mereka seringkali ikut dalam pemerintahan. Memang ada ulama yang tidak ikut dalam pemerintahan, namun posisinya seringkali tidak kuat untuk bersikap kritis terhadap pemerintah, dikarenakan basis sosio-ekonominya yang lemah. Untuk mengatasi hal itu Wahid memaknai pendekatan fiqih sebagai pendekatan sosio-kultural, dimana

1 Pendekatan ideologi bisa mengarah munculnya kekerasan bila ideologi dimaknai secara eksklusif, yang menutup dialog dengan sistem ideologi lainnya. Lihat Stephen Vertigans, "Militant Islam and Weber's Sosial Closure: Interrelated Secular and Religious Code of Exclusion", Contemporary Islam, 2007. hal. 303. 
dia juga menggarap basis sosial ekonomi masyarakat sebagai penyangga eksistensi nilai-nilai Islam. Bahkan dia mengajak Muslim bekerjasama dengan umat beragama lain dalam memajukan sektor publik, seperti menegakkan demokrasi.

Memang Wahid berusaha melakukan pembaharuan dalam Islam yang memungkinkan Muslim merespon secara aktif terhadap isu-isu modernitas. Dalam menjawab isu-isu modernitas itu Wahid tetap menggunakan "kosmologi Islam", yang memandang kehidupan duniawi memiliki dimensi religius: sebagai manifestasi keimanan kepada Tuhan, sehingga dia bersikap kritis terhadap teori sekulerisasi dalam memandang hubungan agama dan negara di era modern ini. Baginya teori sekulerisasi harus didekati dengan pendekatan sosio-kultural: sebagai suatu proses untuk mensintesakan antara "ideal" dengan "realitas sosial", karena teori sekulerisasi harus ditujukan pada terciptanya pemerintahan demokratis. Sekulerisasi ditujukan untuk menghindari terjadinya politisasi agama maupun sakralisasi politik, sehingga perlu pemisahan managemen urusan negara dengan managemen urusan agama. check and balance antara negara dengan masyarakat. Jadi dia tidak setuju bila teori sekulerisasi diperlakukan sebagai ideologi: sekulerisme.

\section{B. Pendekatan Fiqih}

Pada masa regim Presiden Soekarno, kelompok modernis menuduh NU bersikap pragmatis dalam mendukung Negara Kesatuan Republik Indonesia (NKRI), yang dinilainya sekuler, dan tidak serius memperjuangkan negara Islam. Saya kira cap pragmatis tidak tepat dialamatkan ke NU karena ada alasan yang melandasinya dan memang sebagai ormas keagamaan NU memandang kehidupan selalu dari sudut pandang agama, yang dikenal dengan pendekatan fiqih ${ }^{3}$, mengikuti Tradisi Sunni ${ }^{4}$, yang bersikap netral dalam masalah negara: memandang negara tidak dari bentuknya Islam atau non-Islam tetapi dari fungsinya bagi terselenggarakannya tertib sosial, sebagai prasyarat bagi tertib agama. Berdasarkan pendekatan fiqih pula Wahid menilai hubungan Islam dan negara tidak bersifat

2 Abdurrahman Wahid ed., Ilusi Negara Islam: Ekspansi Gerakan Islam Transnasional di Indonesia, (Jakarta: The Wahid Institute, 2009), hal. 12-13.

3 M. Ali Haidar, Nahdatul Ulama dan Islam di Indonesia: Pendekatan Fiqib dalam Politik, (Jakarta: Gramedia, 1998)

4 Tradisi Sunni dikenal dengan Tradisi Pemikiran Aswaja (Ablul Sunnab wal Jama’ah). 
teokratis. Pendekatan fiqih atau pendekatan agamis dan seringkali disebut pendekatan spiritual karena sangat kental dimensi spiritualnya. Wahid sangat menekankan pendekatan spiritual ini, bahkan dalam lembaga yang melibatkan non-Muslim seperti LibForAll digunakan pendekatan spiritual untuk menumbuhkan kesadaran yang mampu mendorong transformasi individual maupun sosial, dengan sasaran membentuk pribadi-pribadi yang tenang dan damai (al-nafs al-muthmainnab) atau manusia yang berakhlak mulia dan menjadi representasi kehadiran spiritualitas atau khalifat Allah yang sebenarnya (dalam konteks Mahabharata, para Pandawa) ${ }^{5}$.

Pemikiran Wahid memang sangat religius, sebagaimana diungkapkan dalam pandangannya mengenai hukum Islam:

Hukum Islam sebenarnya lebih tepat dinamai "keseluruhan tata kehidupan dalam Islam....Hukum Islam, selain mengandung pengertian hal-hal yang lazimnya dikenal sebagai bidang yuridis, juga meliputi soal-soal liturgy dan ritual keagamaan, soal-soal etika dari cara bersopan santun hingga kepada spekulasi estetis dari para mistikus, soal perdata, perdagangan dan niaga, pidana, kenegaraan, dan intenasional. Karena kedudukannya yang begitu memusat, hukum Islam tidak hanya turut menentukan pandangan hidup dan tingkah laku para pemeluk agama itu saja,tetapi ia justru menjadi penentu utama bagi pandangan hidup yang dimaksud. ${ }^{6}$

Pendekatan spiritual bisa juga dinamakan pendekatan kultural karena tidak berpretensi untuk mengubah "struktur" yang ada, seperti peran pimpinan agama yang hanya mengajarkan agama bagi perbaikan pribadi. Namun pendekatan kultural bisa mengarah pada "ideologi kultural” yang menuntut penciptaan masyarakat Islam yang tuntas seperti kasus jilbab. Hal ini cenderung reaktif dengan berbagai tuntutan, yang bisa mengarah kepada penentangan terhadap struktur kekuasaan yang ada dan seringkali mengarah kepada kekerasan yang tidak seimbang. ${ }^{7}$ Wahid sangat perhatian terhadap masalah kekerasan ini, karena dia sangat komitemen dengan demokrasi yang mengimplisitkan tidak adanya unsur kekerasan. ${ }^{8}$

Berkaitan dengan ilmu Wahid mengutip pendapat D.B. MacDonald bahwa 'Syari'ab (Islamic Law) is the science of all things, human and divine'. Pendekatan

5 Abdurrahman Wahid ed., Ilusi Negara Islam: Ekspansi Gerakan Islam Transnasional di Indonesia, (Jakarta: The Wahid Institute, 2009), hal. 12-13.

${ }^{6} \quad$ Ibid., hal. 35.

7 Abdurrahman Wahid, Prisma Pemikiran Gus Dur, (Yogyakarta, LKiS, 1999), hal. 30-31.

8 Abdurrahman Wahid eds. All, Islam tanpa Kekerasan, (Yogyakarta, LkiS, 1998), hal. 72.

9 Abdurrahman Wahid, Prisma Pemikiran Gus Dur, (Yogyakarta, LKiS, 1999), hal. 35. 
spiritual $^{10}$ nampak jelas disini, dimana Wahid memaknai syariah sebagai hasil dialektika aspek agama dan duniawi dan karenanya perlu reinterpretasi syariah secara berkelanjutan. Sikap religius ini yang dikembangkan Wahid dalam kehidupan, mengikuti Tradisi Sunni yang senantiasa bersifat toleran, moderat, dan seimbang. Sikap terbuka Tradisi Sunni ditunjukkan dengan pengakuannya terhadap dua bidang ilmu yang berbeda, yaitu materi dan spirit. Dengan dasar itu dia mengakui metode mendapatkan ilmu berdasarkan pancaindera dan metode mendapatkan ilmu melalui olah hati, dimana Tuhan memberikan ilmu melalui ilham. Lalu semua ilmu akan dikonsultasikan pada Tuhan sebagai sumber utama ilmu. Baginya hidup merupakan jalan panjang untuk mencari kebenaran ${ }^{11}$ dan mengaktualisasikannya dalam kehidupan dengan kesabaran, ${ }^{12}$ mengingat nilai-nilai normatif eksisitensinya terkait dengan konteks dan karenanya kebenaran menjadi bersifat relatif. Walaupun demikian, kebenaran relatif harus dijalankan bagi perbaikan kehidupan secara bertahap. Eksistensi kebenaran tidak independen, tetapi harus diarahkan pada terciptanya tertib sosial dan tertib agama.

Mengingat kebenaran yang universal itu senantiasa terkait dengan konteks maka dia berusaha menyingkap konteks itu melalui berbagai ilmu modern baik filsafat maupun ilmu-ilmu sosial, untuk selanjutnya ditilik dengan kosmologi Islam. Dengan kata lain, penguasaan Wahid terhadap filsafat dan ilmu-ilmu sosial modern harus dikonsultasikan dengan ilmu agama. Hal ini tidak berarti ilmu agama lebih penting dari ilmu duniawi karena keduanya saling melengkapi. Walaupun Wahid pengagum Karl Marx, seperti tertera dalam salah satu sub-bab artikelnya "Gerakan Keagamaan dalam Perspektif Struktural", ${ }^{13}$ namun dia tidak bersifat determinis seperti Karl Marx yang meyakini kalau sejarah umat manusia digerakan oleh materi.

10 Munir Mulkhan juga meyakini perlunya Tradisi Sufi untuk mengatasi krisis dunia modern, namun dia menyebutnya 'kecerdasan makrifat' (Ma'rifat Quotient (MaQ), sebagai kritiknya terhadap teori kecerdasan rasional (Intellectual Quotient (IQ), teori kecerdasan emosional (Emotional Quotient (EQ), maupun teori kecerdasan spiritual (Spiritual Quotient (SQ). Lihat Abdul Munir Mulkhan, "Membangun Kecerdasan Makrifat (Ma'rifat Quotients)", dalam Hery Sucipto ed., 2007, Islam Madzhab Tengab: Persembahan 70 Tahun Tarmizi Taher, (Jakarta: Grafindo Khazanah Ilmu, 2007), hal. 55.

11 Sebagaimana Syafi'i Maarif yang meyakini kebenaran sebagai motor penggerak sejarah. Lihat A. Syafi'i Maarif, Islam dan Politik di Indonesia Pada Masa Demokrasi Terpimpin (19591965), (Yogyakarta: IAIN Sunan Kalijaga Press, 1988), hal. 5.

12 Abdurrahman Wahid, Islamku Islam Anda Islam Kita, Jakarta: The Wahid Institute, 2007), hal. 229.

13 Abdurrahman Wahid, Islam Kosmopolitan, (Jakarta: Gramedia, 2007), hal. 249. 
Memang Wahid mengakui dunia berjalan mengikuti hukum-hukum alam, namun dia masih percaya adanya Tuhan yang aktif yang bisa campur tangan kapan saja bila itu jadi kehendak-Nya. ${ }^{14}$ Karena kepercayaannya pada Tuhan, materi bukan menjadi tujuan utamanya. Materi harus diarahkan bagi kepentingan Tuhan, yang berarti bagi kebaikan dan juga bagi kemanusiaan. Walaupun ilmu dunia penting bagi eksistensi manusia di dunia, namun sebagai Muslim dia meyakini pemikiran keagamaan menginspirasi pengembangan ilmu dunia. Bagi Wahid, rasionalitasnya tidak mencari argumentasi serba logis dari ilmu-ilmu modern, melainkan yang berpangkal pada integritas ilmu-ilmu agama itu sendiri. ${ }^{15}$ Dan karenanya manusia dituntut terus melakukan dialog antara ilmu spirit (dalam hal ini kebenaran) dengan ilmu materi yang harus termanifestasi dalam kehidupan. Baginya, kehidupan merupakan kemampuan menghubungkan spirit Ketuhanan dengan tindakan (dalam dunia materi), namun dalam pelaksanaannya harus disertai dengan kesabaran, demi terhindarnya kekerasan yang akan menodai harkat kemanusiaan. Dalam istilahnya, dalam kehidupan harus selalu mencari keseimbangan antara "normatif (ajaran agama)" dengan "kebebasan berpikir" (dalam urusan duinia). ${ }^{16}$

Memang Wahid menandaskan pentingnya ilmu agama, dalam hal ini sufisme baik itu praktis maupun spekulatif, karena peranannya yang central sebagai pemersatu baik dalam intelektual maupun sosial. ${ }^{17}$ Sufisme praktis mendorong orang melakukan kegiatan sosial secara ikhlas, sedangkan sufisme spekulatif dapat mengintegrasikan intelek dengan spirit Tuhan. Dalam melakukan aktivitasnya Wahid dibimbing oleh pandangan sufistik ini, sehingga dia bisa berbuat secara ikhlas demi mengharap ridla Allah. Adopsinya terhadap sufisme merupakan konsekuensi dari pendekatan sosio-kultural yang dikembangkannya. Walau demikian, dia tidak memutlakkan sufisme dalam kehidupan, dimana dia menilai sufisme sebagai perkembangan lebih lanjut dari syariah, sehingga sufisme harus didialektikan dengan syariah yang diakui masyarakat. Hal ini menunjukkan dia konsisten dengan pendekatannya yang sosio-kultural.

14 Wahid berbeda dengan para founding fathers Amerika yang menganut Deisme, yang memang meyakini adanya Tuhan, namun bukan Tuhan yang aktif, yang bisa intervensi dalam urusan manusia.

15 Abdurrahman Wahid, Kyai Nyentrik Membela Pemerintah, (Yogyakarta: LKiS, 1999), hal. 33.

16 Abdurrahman Wahid, Prisma Pemikiran Gus Dur, (Yogyakarta, LKiS, 1999), hal. 21.

17 Abdurrahman Wahid dalam pengantarnya terhadap buku Syed Hussein Nasr, Islam Antara Cita dan Fakta, terj. Abdurrahman Wahid dan Hasyim Wahid, (Yogyakarta: Pustaka, 2001), hal. xiii. 
Pendekatan sosio-kultural mensyaratkan adanya dialektika antara individu dengan masyarakat. Memang pada tataran individu keyakinan bersifat mutlak, namun ekspresinya dalam masyarakat harus melalui public discourse untuk memenuhi pertimbangan situasi dan kondisi maupun sejarah perkembangan masyarakat itu. Dengan demikian, dalam diri inidividu senantiasa terjadi dialektika antara yang "absolut" dengan yang "partikular". Hal ini sejalan dengan Mahmud Syaltut yang menyakini adanya dua sisi ajaran agama, yaitu sisi ną̧hary dan sisi 'amaly. Atau bisa dikatakan ada dua sisi ajaran, yaitu bersifat "kedalam" dan "keluar". Sisi nazhary (sisi teoritis), berkaitan dengan benak dan jiwa, sehingga ia harus dipahami sekaligus diyakini. Apabila sumber interpretasi ajaran ini dipastikan kebenarannya, ia dinamakan akidah. Sisi 'amaly adalah yang berkaitan dengan pengalaman dalam dunia nyata, yang dinamakan syari'ah. ${ }^{18}$

Pandangan Wahid terhadap sufism sejalan dengan filsuf perenialis seperti Syed Hussein Nasr, yang menandaskan kesatuan dari agama-agama. Mereka melihat agama meliputi aspek_eksoterik (aspek luar) dan aspek esoteris (aspek dalam). Secara eksoteris, ada beberapa identitas agama seperti Yahudi, Kristen, dan Islam. Sedangkan secara esoteris semua identitas agama itu mengakui adanya spiritualitas yang bersumber dari Tuhan. Para filsuf perenialis meyakini pluralitas agama merupakan suatu yang kodrati, bahkan dalam suatu agama memungkinkan adanya penafsiran yang berbeda, demi memenuhi mentalitas keberagama yang berbeda. Bukankah dalam Islam lahir Sunni, Syiah, Muhammadiyah, NU, dan PKS. Walau demikian Wahid mengkritik Nasr yang terlalu menekankan aspek kontemplatif dan terlalu mengidealisir tradisionalisme dalam Islam. Wahid mengatakan Nasr terlalu menjauhi kebutuhan menghadapkan berbagai aspek perkembangan Islam satu dengan yang lain dalam bentuk konfrontatif, seperti antara fiqih dan tasawuf, sehingga banyak pelajaran yang mungkin dapat diambil dari sebuah dinamika yang intens luput dari pengamatannya. ${ }^{19}$

Demokrasi bisa dipahami sebagai bentuk penerapan nilai-nilai universal Islam dalam konteks modern. ${ }^{20}$ Penerimaan Islam terhadap 'bentuk' (konsep demokrasi) dengan di-'isi' (dengan nilai-nilai universal Islam) merupakan usaha mempertemukan antara 'budaya' ('adah) dengan 'norma' (syariah), sebagaimana menjadi persoalan ushul al-figh. ${ }^{21}$ Mengingat proses pewahyuan sudah berhenti maka Wahid meyakini

18 Achmad Mufid, Nyleneh Itu Indah, (Yogyakarta: Kutub, 2010), hal. 73-74.

19 Syed Hussein Nasr, Islam Antara Cita dan Fakta, terj. Abdurrahman Wahid dan Hasyim Wahid, (Yogyakarta: Pustaka, 2001)

20 Achmad Mufid, Nyleneh Itu Indah, (Yogyakarta: Kutub, 2010), hal. 41 dan 5.

21 Ibid., hal. 4. 
perlunya reinterpretasi terhadap kitab suci agar nilai-nilai universalnya dapat diterapkan dalam situasi yang terus berubah. ${ }^{22}$ Dia meyakini Muslim perlu merespon isu-isu modern berdasarkan Tradisi Islam. Karena itu dia tidak setuju dengan sekulerisasi model Turki yang tidak memberi kesempatan pada komunitas agama (Islam) untuk mengekspresikan pemikirannya mengenai isu-isu modernitas. Dengan demikian pemikiran Wahid tentang teologi demokrasi merupakan responnya terhadap isu demokrasi dari perspektif Tradisi Islam. Pemahaman Muslim tentang teologi demokrasi tidak perlu bertentangan dengan ekspresi mengenai topik yang sama dari non-Muslim, karena dalam sektor publik, suatu "pernyataan" boleh dipahami secara berbeda sesuai dengan keyakinan masing-masing kelompok. ${ }^{23}$ Contoh: Muslim bisa mengucapkan "Selamat Natal" sesuai dengan keyakinannya (seperti tertera dalam Al-Qur'an), sedangkan non-Muslim bisa memahaminya sesuai dengan akidahnya. ${ }^{24}$ Dalam kehidupan sosial, tidak perlu semua masalah dicari kebenaran finalnya, yang penting semua pihak sepakat mewujudkan kondisi yang memungkinkan bagi berlangsungnya kebaikan berikutnya. Contohnya dalam konflik rumah tangga antara suami isteri, tidak perlu dicari mana yang salah dan mana yang benar, yang penting mereka sepakat bekerjasama bagi kebaikan keluarga. Dengan demikian, dalam pergaulan sosial kebenaran bukan segalanya, namun bukan berarti kebenaran tidak penting: kebenaran tetap penting namun harus ada pemahaman bahwa anggota masyarakat memiliki kadar pemahaman yang berbeda-beda mengenai kebenaran. Memang dalam berhubungan dengan orang lain kebenaran berkaitan dengan relasi ${ }^{25}$, sehingga kebenaran perlu disampaikan secara bertahap dengan penuh kesabaran. Memang bagi subyek, kebenaran adalah mutlak.

Pengakuan eksistensi kelompok (agama) itu bersifat timbal balik -bagimu agamamu dan bagiku agamaku. Masing-masing pihak dapat melaksanakan apa yang

22 Agus Maftuh, , "Mazhab Islam Kosmopolitan Wahid”, dalam Abdurrahman Wahid, Islam Kosmopolitan, (Jakarta: Gramedia, 2007), hal. vii. Epistemologi 'fenomena sosial yang tak terbatas' (alwaqa'I ghair al-mutanabiyah) dikaitkan dengan 'teks keagamaan yang terbatas' (al-nusus al-mutanabiyah), yang menjadi adagium Ibnu Rusyd dalam pembukaan kitab Bidayat al-Mujtabid wa Nihayat al-Muqtasid.

23 Ratno Lukito menjelaskan bagaimana tradisi hukum yang berbeda bisa mencapai suatu konsensus terhadap suatu permasalahan. Lihat Ratno Lukito, Hukum Sakral dan Hukum Sekuler: Studi tentang Konflik dan Resolusi dalam Sistem Hukum Indonesia, (Jakarta: Pustaka Alvabet, 2008), hal. 14.

24 Abdurrahman Wahid, Islam Kosmopolitan, (Jakarta: Gramedia, 2007), hal. 33.

25 Bandingkan dengan pandangan Harold H. Saunders, "Relational Realism: Toward a New Political Paradigm for Security", in Robert A. Sieple n Dennis R. Hoover, eds., 2004, Religion and Security, (New York: Rowman \& Littlefield Publishers, Inc. 2004), hal. 164. 
dianggap benar dan baik, tanpa memutlakkan pendapatnya kepada orang lain, tetapi sekaligus tanpa mengabaikan keyakinan yang absolut itu. Mengapa hal ini dapat dirumuskan? Karena absolusitas adalah sikap jiwa ke dalam, tidak menuntut pernyataan dan kenyataan dari luar bagi yang tidak meyakininya. Ketika kaum musyrik bersikeras menolak ajaran Islam maka demi kemaslahatan bersama, Tuhan memerintahkan kepada Nabi Muhammad SAW untuk berkata: "Sesungguhnya kami atau kamu yang berada dalam kebenaran, atau dalam kesesatan yang nyata, kamu tidak akan diminta mempertanggungjawabkan pelanggaran-pelanggaran kami dan kamipun tidak akan diminta mempertanggungjawabkan perbuatan-perbuatan kamu, katakanlah: Tuhan kelak akan menghimpun kita semua, kemudian Dia memberi keputusan diantara kita dengan benar. Sesungguhnya Dia Maha Pemberi keputusan lagi Maha Mengetahui." 26

Tindakan dialektis seperti ini merupakan panggilan sejarah seorang umat beragama yang hendak memperbaiki kehidupan duniawi. Adalah mungkin bagi manusia untuk mempercayai ilmu materi saja seperti Karl Marx dan dia mungkin akan sukses dalam urusan dunia. Namun tidak dapat dipastikan dia merasa bahagia dalam hidupnya karena kebahagiaan tidak terletak pada materi semata. Kebahagiaan merupakan suasana psikologis berkaitan dengan perasaan aman. Perasaan bahagia tidak akan didapat bila manusia tidak bisa mengontrol ambisinya atau dia tidak dapat mewujudkan keinginannya seperti perasaan dicintai. Sementara sebagian umat beragama hanya mempercayai ilmu spirit saja dan dia akan selalu berusaha mendekatkan diri kepada Tuhan dengan menjalankan ritus-ritus agama dan doadoa sebagai latihan olah hati. Hal itu tentu dilakukan demi mendapatkan perasaan aman dan bahagia tanpa berusaha mendapatkan kepuasan materi.

Wahid mengikuti cara yang ditempuh oleh Nabi Muhammad SAW. Bukankah Nabi tidak larut dalam gapaian spiritualnya ketika mencapai puncak eksistensi dalam peristiwa Isra Mi'raj dan beliau kembali ke realitas masyarakat kongkrit mengajak untuk mewujudkan kebahagiaan. ${ }^{27}$ Spiritualitas itu menjadikan Nabi tidak kenal lelah dalam melakukan misi Dakwah Rahmatan lil 'Alamin. Inilah spirit untuk Ketuhanan dan kemanusiaan sekaligus, yaitu misi bagi perbaikan kehidupan (duniawi) manusia yang dijiwai nilai-nilai Ketuhanan (berupa kebenaran). Misi

26 Achmad Mufid, Nyleneh Itu Indah, (Yogyakarta: Kutub, 2010), hal. 74-75.

27 A. Munir Mulkhan, "Islam Ideologi dan Islam Budaya" dalam M. Fahmi Islam Transendental: Menelusuri Jejak-Jejak Pemikiran Islam Kuntowijoyo, (Jakarta: Pilar Religia, 2005), hal. xxv-xxvi. 
Rahmatan lil 'Alamin dapat diartikan sebagai "Islam dan Misi Peradaban", dimana dakwah tidak hanya ditujukan kepada masyarakat Muslim, tetapi bagi semua manusia tanpa membeda-bedakan latar belakang primordialnya. Dakwah peradaban tidak hendak memperkenalkan doktrin-doktrin agama yang bersifat normatif, namun berusaha mengejawantahkan nilai-nilai universal Islam dengan cara ikut mengentaskan permasalahan kemanusiaan. Untuk keperluan itu perlu penguasaan ilmu-ilmu duniawi sebagai pisau analisanya, yang tentunya harus ditempatkan dalam kaca mata kosmologi Islam. Pendekatan peradaban juga memungkinkan Muslim membangun kerjasama yang tulus dengan non-Muslim, seperti dalam menegakkan demokrasi di Indonesia.

\section{Pendekatan Sosio-Kultural}

Orang sering salah menilai Wahid mendukung pendekatan kultural dalam hubungan antara Islam dan negara, karena dalam artikelnya yang ditulis tahun 1984 dan kemudian dijadikan buku "Islam dan Militerisme dalam Lintasan Sejarah" ditulis sub-bab "Perlawanan Kultural" yang mengesankan dia mendukung pendekatan kultural. Namun bila kita membaca sub-bab itu secara utuh maka kita akan mendapatkan kritiknya: perlunya pendekatan kultural merumuskan kembali tujuan perlawanannya, orientasinya maupun metode yang digunakan. Berikut pendapatnya:

Perlawanan kultural tersebut akan mencapai tujuannya apabila diletakkan dalam kerangka lebih luas dari apa yang dimilikinya selama ini. Ia tidak lagi cukup hanya menjadi ekspresi keimanan sebagai muslim untuk menegakkan ajaran formal Islam belaka, tetapi harus menjadi bagian dari upaya kemanusiaan umum untuk membebaskan rakyat yang tertindas dari belenggu kenistaan, kehinaan dan kepapaan yang menurunkan derajatnya sebagai makhluk mulia. Untuk itu dituntut dari gerakangerakan perlawanan kultural kaum muslimin agar terlebih dahulu mampu hidup bersama dengan manusia dari agama-agama lain, ideologi politik dan pandangan budaya, yang memiliki kesamaan pandangan dasar tentang hakikat tempat manusia dalam kehidupan dan cara-cara untuk mewujudkannya. ${ }^{28}$

Dari kritik Wahid terhadap pendekatan kultural kita bisa menempatkan Wahid sebagai pencetus pendekatan sosio-kultural. Pendekatan sosio-kultural yang dikembangkan Wahid merupakan hasil sintesa dari kosmologi Islam dengan pendekatan struktural yang diperkenalkan Karl Marx. Wahid bersikap kritis terhadap pendekatan struktural yang bertujuan mengganti struktur (sistem) yang ada dengan sistem baru dengan cara revolusi. Yang dimaksud dengan pendekatan sosio-kultural

28 Abdurrahman Wahid, Prisma Pemikiran Gus Dur, (Yogyakarta, LKiS, 1999), hal. 67. 
adalah hendak melakukan perubahan kultural secara sadar, yang akan menghindari terjadinya kekerasan secara tidak seimbang, dan hendak melakukan perubahan struktur secara evolusioner melalui level masyarakat, bukan pada level negara. Dengan pendekatan sosio-kultural, agama tidak hanya bagi keperluan spiritualitas pribadi, namun juga bagi nilai yang akan menjiwai masyarakat, termasuk masyarakat politik (negara). Karenanya Wahid melihat Negara Pancasila merupakan negara sekuler yang tidak sekulerism. Baginya Pancasila harus dimaknai sebagai ideologi terbuka yang harus menjunjung tinggi mekanisme demokrasi.

Perubahan struktural yang ditawarkan Wahid beda dengan yang dilakukan oleh Karl Marx karena dia tidak membenarkan adanya revolusi. Baginya perubahan harus dilakukan secara demokratis dengan menghindari terjadinya kekerasan. Sikap itu ditempuh berdasarkan keyakinannya tidak adanya bentuk negara ideal yang harus diperjuangkan dengan segala cara. Hal ini berbeda dengan Karl Marx yang meyakini bentuk negara ideal komunis yang harus diperjuangkan secara revolusi oleh kaum proletar melalui serangan langsung pada jantung kekuasaan negara. ${ }^{29}$ Bagi Karl Marx, kekuasaan (negara) merupakan tujuan, walaupun dengan justifikasi hendak mewujudkan kesejahteraan bagi kaum buruh. Sementara Wahid menganggap kekuasaan sebagai alat untuk mewujudkan kesejahteraan, sehingga dia bisa bekerjasama dengan mereka yang bekerja dalam sistem negara bagi pengembangan kesejahteraan masyarakat. Dia pun mau bekerjasama dengan regim Soeharto dalam mengembangkan kelompok-kelompok masyarakat yang berafiliasi dengan NU. Pengembangan masyarakat dimaksudkan mengugah kesadaran rakyat agar sadar akan kedudukannya sebagai makhluk yang bermartabat dan karenanya sadar untuk terus mengontrol negara agar tidak mengingkari harkat kemanusiaan. Dalam hal ini Wahid berusaha membangun NU sebagai Civil Soceity. Memang dalam mengontrol negara dilakukan melalui berbagai level struktur masyarakat mulai dari komunitas sampai tingkat negara, bahkan sampai tingkal global. Dia sangat menekankan perlunya check and balance karena dalam pandangannya hukum kehidupan bersifat realis, dimana dia melihat power seringkali dilepaskan dari pandangan moralitas. ${ }^{30}$ Karenanya dia berkeyakinan bahwa:

Memang utopis untuk mengharapkan perlawanan kultural itu mampu menumbangkan rezim-rezim militer dalam waktu singkat, namun kemampuannya

29 Ibid., hal. 30-31.

30 Maman Imanulhal Faqieh, Fatwa dan Canda Gus Dur, (Jakarta: Kompas, 2010), hal. 176. 
untuk survive dari tekanan dan penindasan menunjukkan potensinya untuk melakukan hal itu dalam jangka panjang, mungkin setelah memakan waktu ratusan tahun. $^{31}$

Pentingnya pendekatan struktural dalam pemikiran WAHID nampak dalam artikelnya "Republik Bumi di Surga: Sisi Lain Motif Keagamaan di Kalangan Gerakan Masyarakat", dimana dia yakin bahwa:

Islam membawa ajaran agama yang berwatak kemasyarakatan dan sepenuhnya disandarkan pada pranata-pranata institusional untuk menerapkannya dalam kehidupan. Bahkan aspek kehidupannya yang paling meditative dan kontemplatif sekalipun, yaitu tasawuf, masih harus menanggung beban institusional atas kehidupan ini mendorong kepada penghadapan dengan bentuk-bentuk kemasyarakatan lainnya, dengan dampaknya sendiri atas kebutuhan mengembangkan pranata kemiliteran dalam lingkungannya sendiri. ${ }^{32}$

Pentingnya pendekatan struktural terlihat dalam penilaiannya terhadap eksistensi pesantren yang selama ini pesantren dinilai mampu bertahan menghadapi bermacammacam gempuran, adalah disebabkan oleh kekokohan basis sosial ekonomi pesantren. Oleh karena itu, tugas yang lalu dipandang penting adalah mengembangkan kekuatan sosial ekonomi masyarakat yang mulai menurun, sehingga dirasakan perlunya menggalakkan pelajaran ketrampilan dan ilmu-ilmu modern di pesantren, walaupun jangan sampai menurunkan misi utama mencetak kiai. ${ }^{33}$

Pendekatan sosio-kultural mensyaratkan dilakukan pendekatan historis_terhadap Islam, dimana dia sampai pada keyakinan bahwa Islam tersebar di seluruh penjuru dunia justru mengambil corak perlawanan kultural. Datangnya Islam ke kawasan Asia Tenggara, Asia Tengah dan Afrika Hitam dilakukan oleh kaum sufi dan pedagang, tidak oleh militer sebagai representasi negara Islam. ${ }^{34}$ Masuknya Islam ke daerah yang begitu jauh dan luas terjadi secara kultural, dimana ajaran-ajaran Islam berhasil masuk ke dalam ranah etik sosialnya (socio ethic) maupun pandangan hidupnya (personal ethic). Bahkan tidak ada satupun ideologi formal negara (political ethic) yang mayoritas penduduknya beragama Islam dapat memaksakan ketundukan mutlak kepada ideologi itu sendiri. Karena tetap saja ada tolak ukur atau titik bandingan terhadap ideologi formal negara dalam hati kaum muslimin: sesuaikan

31 Abdurrahman Wahid, Prisma Pemikiran Gus Dur, (Yogyakarta, LKiS, 1999), hal. 66.

32 Ibid., hal. 183.

33 Abdurrahman Wahid, Menggerakkan Tradisi Pesantren, (Yogyakarta: LkiS, 2001) ,hal. 145-146.

34 M. Amin Syukur, "Keseimbangan Perkembangan Tasawuf dan Fiqh di Indonesia" dalam Epistemologi Syara': Mencari Format Baru Fiqh Indonesia, Yogyakarta: Pustaka Pelajar, hal. 20. 
ideologi tersebut dengan keyakinan agama, adakah para agamawan diberi hak turut menentukan keputusan-keputusan dasar di bidang kenegaraan, dan mungkinkah ajaran Islam dilaksanakan dengan damai di seluruh wilayah negara? ${ }^{35}$

Pendekatan sosio-kultural merupakan suatu cara untuk mendamaikan pemikiran politik dari dua kubu ekstrim antara kaum idealis dengan kaum realis. Kaum idealis percaya bahwa kehidupan harus ditundukkan pada nilai-nilai normatif yang sudah baku, sedangkan kaum realis percaya bahwa power memiliki daya yang kuat untuk mengatur kehidupan. Yang pertama bisa mengarah pada kecenderungan memaksakan orang (atau kehidupan) tunduk pada nilai-nilai normatif yang diyakini sudah baku dan berada di luar dirinya. Mereka menilai kebenaran harus ditegakkan dengan segala cara. Yang kedua berkeyakinan power yang menentukan kehidupan sehingga kehidupan selalu diliputi dengan kompetisi untuk mendapatkan power yang terbatas. Pendekatan sosio-kultural berpretensi untuk mengatasi kedua pandangan ekstrim itu. Bagi Wahid, power harus dibimbing dengan nilai-nilai normatif agar kehidupan diliputi suasana damai dan tentram. Namun implementasi dari nilai-nilai normatif itu disesuaikan dengan situasi dan kondisi agar tidak terjadi kekerasan, karena baginya kebenaran bukan segalanya namun harus ditujukan pada kehidupan yang aman dan damai. Baginya kehidupan merupakan suatu usaha untuk mensintesakan antara nilai-nilai yang normatif dengan konteks, tempat power diperebutkan. ${ }^{36}$

Pendekatan sosio-kultural ingin keluar dari ketegangan akut dalam tradisi filsafat politik mulai dari Plato, Kant, Hegel, Marx dan pemikir-pemikir modern lainnya. Ketegangan ini bersumber dari konflik abadi mengenai apakah truth (kebenaran) sudah melekat dalam dirinya (buman nature) atau dibuat (created), terintegrasi dalam diri subyek 'bere inside' atau ataukah ditemukan (discovered) dan mengembara di luar diri subyek (out there)? Jawaban atas pertanyaan ontologis ini membawa kita untuk membedakan dua fakultas besar dalam filsafat politik yakni fakultas privat dan fakultas publik. Filsafat politik yang masuk dalam fakultas privat seperti relativisme, skeptisisme, ataupun skeptisisme radikal (postmodernisme) dan sejumlah filsafat hermeneutik semacam Wittgenstein, yang berpegang teguh dan menjawab bahwa kebenaran (etik) secara integral telah berada dalam diri subyek sehingga tugas subyek dalam dunia sosialnya bukan lagi mencari kebenaran tersebut, melainkan

35 Abdurrahman Wahid, Prisma Pemikiran Gus Dur, (Yogyakarta, LKiS, 1999), hal. 64.

36 Abdurrahman Wahid, Kyai Nyentrik Membela Pemerintah, (Yogyakarta: LKiS, 1999), hal. 2 
mengaktualkan. Sementara pada pihak lain, fakultas publik berpandangan bahwa tugas subyek adalah mengembara menemukan kebenaran yang berada di luar dirinya. Implikasi dari dua sikap ini jelas, yang pertama lebih mendisiplinkan diri untuk kembali kepada self dan mengklaim kembali konsep Nietsche mengenai superman, melakukan upaya self-creating (Foucault menyebutnya aesthetic atau technic of self), bersifat pragmatis dan relatif. Sementara itu, yang kedua (publik) lebih menitikberatkan kepada penciptaan sarana-sarana emansipatif serta standar-standar normatif, utopia. ${ }^{37}$

Dari pembelahan ini tugas filsafat politik kemudian juga terpisah menjadi dua bagian. Bagian pertama lebih memfokuskan diri pada pembongkaran bentuk-bentuk kuasa atas tubuh (politics of body), bahasa ataupun diskursus. Sedangkan bagian kedua lebih memfokuskan kepada tema-tema besar (grand narrative) serta bagaimana mencapai tujuan-tujuan pembentukan struktur sosial dan hubungan sosial yang emansipatif (dalam istilah Habermas) atau adil atau fair (dalam istilah Liberal semacam Rawls). Kebanyakan filsafat dalam golongan kedua ini mengklaim bahwa tujuan utama filsafat hanya dapat dilihat dari pengaruhnya terhadap output dalam politik seperti emansipasi dan sebagainya, sehingga dengan demikian filsafat dan politik akan berguna hanya dengan mengabdi kepada tujuan-tujuan ideal (etik utopia). ${ }^{38}$

Secara ontologis, dilihat dari eksplanasinya mengenai jarak antara subyek dengan kebenaran serta tugas abadi subyek mencari kebenaran di luar dirinya, tergambar semacam klaim bahwa tugas dari ilmu pengetahuan, filsafat, ataupun teori baru akan bisa terpenuhi hanya apabila tercapai pertemuan sejati antara subyek dan kebenaran tersebut, karena di dalam momentum itulah subyek berkesempatan mengklaim kepenuhannya dan seluruh ideal-idealnya. Di wilayah filosofis kita menemukan pandangan semacam ini, misalnya filsafat politik Plato tentang 'tubuh' yang mencapai 'jiwa' ataupun filsafat dialektika Hegel mengenai 'absolute kebenaran', ataupun pikiran Marx mengenai 'masyarkat komunis masa depan' sebagai dasar normatif perjuangan kelas di masa kapitalis. Impliksi yang mungkin dari sistem berpikir ini adalah kemajuan (ide progress) hanya dilihat dan hanya mungkin dinikmati apabila suatu final momentum itu tercapai (subyek=kebenaran), sebelum itu tidak ada yang boleh diklaim sebagai progres. ${ }^{39}$

37 Tim INCReS, 2000, Beyond the Symbol, Bandung: Rosdakarya, hal. 43.

38 Robertus Robert, 2004, "Emansipasi, Tradisi dan Kontinjensi: Politik Radikal dalam Skeptisisme Neo-Liberal” Mandatory Edisi 1/Tahun 1, IRE, hal. 14-16.

39 Ibid. 
Akibatnya, mereka sama sekali tidak memperhitungkan 'masa' dan 'jarak' tempuh pengembaraan subyek yang tentu saja telah mengubah karakter subyek tersebut, sehingga subyek pada titik awal dia 'berangkat' tentu berbeda dengan subyek pada suatu titik waktu tertentu karena subyek telah bergerak dan mengalami suatu proses pengalaman praksis tertentu (baca: praktek mencipta tradisi). Pandangan ini sejalan dengan pernyataan Wahid bahwa NU pada masa berdiri berbeda dengan NU pada masanya karena tiap masa mengendaki jenis responsi yang berbeda dari NU, disamping elit yang mengendalikannya juga berbeda. ${ }^{40}$ Pernyataan itu sejalan dengan pendekatan sosio-kultural yang berusaha mensintesakan antara "normatif" dengan yang "partikular", dimana antara keduanya bisa dipisahkan namun tetap saling berkaitan satu sama lainnya. Begitu juga dengan pemahamannya tentang fakultas privat dan fakultas publik, dimana keduanya dapat dipisahkan namun mereka saling berkaitan satu sama lainnya.

Pemikiran Wahid yang memungkinkan terjadinya dialektika "norm" dengan "particular" berakar dari pandangannya yang tidak membedakan antara urusan dunia dan akherat. Baginya agama tidak hanya mengurusi akherat, tetapi juga urusan duniawi. Pendekatan spiritualnya digunakan untuk menundukkan urusan duniawi berdasarkan nilai-nilai normatif sebagaimana diwahyukan Allah kepada Nabi Muhammad. Dengan demikian pendekatan sprititual dimaksudkan sebagai proses mengaktualkan kebenaran normatif dalam dialognya dengan urusan duniawi yang sangat dipengaruhi oleh konteks spasial dan temporal. Pandangan ini jelas mengoreksi pandangan Wittgenstein, dimana Wahid menyakini manusia harus mencari kebenaran yang kontekstual dan lalu mengaktualkannya. Berkaitan dengan hal ini Wahid mengutip Hasan Hanafi berkaitan dengan "kesadaran aktif yang meliputi aksi dan niatan, yang dari jalinan keduanya ia mencoba memproyektir sebuah kesatuan dunia yang ideal, dalam mana akan tercapai keseimbangan antara pesan abadi yang disampaikan oleh Islam dan aktualitas yang harus dihadapinya dari waktu ke waktu. ${ }^{41}$

Pentingnya pendekatan struktural mengarahkan Wahid menaruh perhatian terhadap masalah negara, yang mempunyai pengaruh sangat besar dalam kehidupan, dimana kekuasaan yang dimiliki oleh institusi negara begitu besar, karena dipandang sebagai puncak dari sistem kemasyarakatan. Dari sejarah dia tahu bahwa hubungan agama dan negara telah menjadi perhatian para pemikir zaman ke zaman, ${ }^{42}$ dan dia

\footnotetext{
40 Abdurrahman Wahid, 1999, Prisma Pemikiran Gus Dur, (Yogyakarta, LKiS, 1999), hal. 166.

41 Ibid., hal. 47.

42 Ibid., hal. 1.
} 
ingin berpartisipasi mencari format yang ideal hubungan agama dan negara. Dia berkeyakinan bahwa keduanya harus saling memberi legitimasi, walaupun dia yakin pada sekulerisasi dalam pengertian adanya pemisahan managemen urusan agama dan agama. Dia tidak setuju penerapan nilai-nilai agama yang partikular dalam negara, dan karenanya dia bukan pendukung formalitas agama. Maslaah hubungan agama dan negara harus diselesaikan secara tuntas, bukan dengan cara-cara penyelesaian sementara, karena hanya akan menunda permasalahan yang sebenarnya. Penyelesaiannya dilakukan secara demokrasi antara berbagai pihak yang terlibat baik itu negara dengan komunitaskomunitas agama maupun antar komunitas agama sendiri.

Pentingnya demorkasi dalam ruang publik merupakan inti pemikirannya, sehingga segala sesuatu yang menyangkut pemikirannya dan juga tindakan politiknya ditujukan bagi tegaknya demokrasi. Wahid mencita-citakan tegaknya masyarakat demokratis, yang di dalamnya harkat dan martabat manusia dihargai. Baginya, konsep demokrasi bukanlah merupakan konsep yang berdiri sendiri, sehingga tegaknya masyarakat yang demokratis juga harus didukung berbagi faktor seperti sosial, ekonomi, budaya, politik, dan pertahanan-keamanan. Misi menegakkan masyarakat demokrasi, terutama masyarakat politik (negara) merupakan tugas sejarah sepanjang masa, karena seperti dikatakan Lord Acton, 'power tends to corrupt', dimana sejarah menunjukkan penyalahgunaan kekuasaan sepanjang masa, padahal sudah ada agama yang bertujuan mereformasi manusia agar menjadi manusia yang baik (beragama). Tidak heran bila agama-agama menaruh perhatian terhadap masalah kekerasan berkaitan dengan power karena masalah power merupakan masalah akut dalam sejarah umat manusia. Berdasarkan latar belakang inilah maka Wahid menganjurkan ormas keagamaan memerankan diri sebagai Civil Society, yang akan memainkan perankan check $n$ balance terhadap negara. ${ }^{43}$

Dalam hal ini orang sering salah paham memahami Wahid sebagai individu dan posisinya sebagai pimpinan ormas keagamaan. Posisi ormas keagamaan tetap tidak berubah sebagai civil society, namun Wahid sebagai individu bisa saja memainkan peran sebagai politisi yang berurusan dengan real politik berkaitan dengan struggle for power. Hal ini dia lakukan ketika dia mendirikan partai politik (PKB), yang digunakan sebagai kendaraan meraih posisi presiden RI. Bahkan ketika dia dilengser dari posisinya sebagai presiden, dia tidak mau menuruti nasehat para koleganya agar meninggalkan partai politik, bahkan sampai dia wafat. ${ }^{44} \mathrm{Hal}$ ini

43 Ibid., hal. 169.

44 Maman Imanulhal Faqieh, Fatwa dan Canda Gus Dur, (Jakarta: Kompas, 2010), hal. 171. 
dilakukan Wahid karena dia sudah tidak menjabat sebagai pimpinan ormas keagamaan NU, disamping pertimbangan pentingnya partai untuk mewujudkan masyarakat demokratis, terutama pada tataran politik, dimana konstitusi dan sistem ketatanegaraan mengharusnya penyaluran aspirasi politik melalui partai. Apakah hal itu berarti Wahid sudah meninggalkan pendekatan sosio-kultural? Saya kira tidak, karena pendekatan sosio-kultural berarti melakukan perubahan politik secara evolusioner. Nah Wahid berusaha memerankan politik yang tidak hendak mengganti sistem politik yang ada baik dalam pemikiran maupun dalam praktik politik yang menggunakan cara-cara kekerasan.

\section{Penutup}

Banyak yang melihat Wahid bersikap pragmatis dalam kehidupan karena dinilai tidak ada dasar yang dijadikan landasan tindakannya. Masykuri Abdillah dalam disertasinya juga meyakini Wahid mengadopsi landasan filosofis demokrasi hanya bersifat pragmatis, mengingat tidak didasarkan pada Tradisi Islam. Berdasarkan pengamatannya intelektual Muslim Indonesia lainnya hanya mengadopsi demokrasi berdasarkan pertimbangan operasional. ${ }^{45}$ Juga pada masa regim Presiden Soekarno, kelompok modernis menilai NU bersikap pragmatis dalam menerima Negara Pancasila. Padahal NU, sebagai ormas keagamaan, senantiasa mendasarkan pada pendekatan fiqih (pendekatan agamis) dalam menjalani kehidupan. Begitu juga dengan Wahid, sebagai seorang ulama, senantiasa mendasarkan pemikirannya berdasarkan Tradisi Islam, seperti yang terkodifikasi dalam kitab kuning. Dalam merespon isu-isu modernitas wahid mendasarkan dirinya pada kosmologi Islam seperti yang tercantum dalam kitab kuning dan dilengkapi dengan tradisi pemikiran, sebagai pisau analisanya, baik itu tradisi liberal, tradisi Marxis, maupun tradisi Muslim modernis.

Memang pemikiran Wahid sudah keluar dari tradisi NU yang cenderung konservatif berkat pemahamannya terhadap filsafat dan ilmu-ilmu modern, sehingga dia memaknai pendekatan fiqih sebagai pendekatan sosio-kultural. Selama ini pendekatan fiqih cenderung dimaknai pendekatan kultural, dimana nilai-nilai Islam didakwahkan secara kultural. Wahid menilai hal itu kurang efektif, mengingat tidak disangga oleh basis sosial-ekonomi masyarakat pendukungnya. Dia juga kawatir dengan pendekatan kultural yang bisa mengarah pada ideologi kultural, karena

45 Masykuri Abdillah, Demokrasi Dipersimpangan Makna, (Yogyakarta: Tiara Wacana. 1999) 
bisa mengarah pada kekerasan yang tidak seimbang. Memang dia bersikap kritis terhadap pendekatan ideologi baik itu Islamisme, komunisme, maupun sekulerisme, karena semuanya cenderung bersikap tertutup terhadap sistem lainnya, dimana seringkali dihadapkan antara "kita" dengan "mereka". Baginya ideologiideologi hanya digunakan sebagai pisau analisa demi terciptanya demokrasi, dengan implikasi harus dihindarinya kekerasan. Karena itu dia tidak setuju dengan revolusi yang ditempuh oleh pendekatan ideologis. Baginya perubahan struktural harus dilakukan secara evolusi, sehingga adanya kesediaan untuk terlibat dalam sistem yang ada.

\section{DAFTAR PUSTAKA}

Abdillah, Masykuri. 1999. Demokrasi Dipersimpangan Makna, Yogyakarta: Tiara Wacana.

Faqieh, Maman Imanulhal. 2010. Fatwa dan Canda Gus Dur, Jakarta: Kompas.

Haidar, M. Ali. 1998. Nabdatul Ulama dan Islam di Indonesia: Pendekatan Fiqih dalam Politik, Jakarta: Gramedia.

Lukito, Ratno. 2008. Hukum Sakral dan Hukum Sekuler: Studi tentang Konflik dan Resolusi dalam Sistem Hukum Indonesia, Jakarta: Pustaka Alvabet.

Maarif, A. Syafi'I. 1988. Islam dan Politik di Indonesia Pada Masa Demokrasi Terpimpin (1959-1965), Yogyakarta: IAIN Sunan Kalijaga Press.

Maftuh, Agus. 2007. "Mazhab Islam Kosmopolitan Wahid”, dalam Abdurrahman Wahid, 2007, Islam Kosmopolitan, Jakarta: Gramedia.

Mufid, Achmad. 2010. Nyleneh Itu Indah, Yogyakarta: Kutub.

Mulkhan, A. Munir. 2005. "Islam Ideologi dan Islam Budaya" dalam M. Fahmi Islam Transendental: Menelusuri Jejak-Jejak Pemikiran Islam Kuntowijoyo, Jakarta: Pilar Religia.

2007. "Membangun Kecerdasan Makrifat (Ma'rifat Quotients)", dalam Sucipto, Hery ed., 2007, Islam Madzhab Tengab: Persembahan 70 Tabun Tarmizi Taher, Jakarta: Grafindo Khazanah Ilmu.

Nasr, Syed Hussein. 2001. Islam Antara Cita dan Fakta, terj. Abdurrahman Wahid dan Hasyim Wahid, Yogyakarta: Pustaka. 
Robert, Robertus. 2004. "Emansipasi, Tradisi dan Kontinjensi: Politik Radikal dalam Skeptisisme Neo-Liberal” Mandatory Edisi 1/Tahun 1, IRE.

Saunders, Harold H. 2004. "Relational Realism: Toward a New Political Paradigm for Security", in Robert A. Sieple n Dennis R. Hoover, eds., 2004, Religion and Security, New York: Rowman \& Littlefield Publishers, Inc..

Syukur, M. Amin. tt. "Keseimbangan Perkembangan Tasawuf dan Fiqh di Indonesia" dalam Epistemologi Syara': Mencari Format Baru Fiqh Indonesia, Yogyakarta: Pustaka Pelajar.

Tim INCReS. 2000. Beyond the Symbol, Bandung: Rosdakarya.

Vertigans, Stephen. 2007. “Militant Islam and Weber's Sosial Closure: Interrelated Secular and Religious Code of Exclusion", Contemporary Islam.

Wahid, Abdurrahman eds.1998. Islam tanpa Kekerasan, Yogyakarta, LkiS.

Wahid, Abdurrahman. 1999. Kyai Nyentrik Membela Pemerintah, Yogyakarta: LKiS. 1999. Prisma Pemikiran Gus Dur, Yogyakarta,LkiS. 2001. Menggerakekan Tradisi Pesantren, Yogyakarta:LkiS. 2007. Islam Kosmopolitan, Jakarta: Gramedia. 2007. Islamku Islam Anda Islam Kita, Jakarta:The Wahid Institute. .2009. Ihusi NegaraIslam:Ekspansi Gerakan Islam Transnasional di Indonesia, Jakarta: The Wahid Institute. 
354 Millah Vol. X, No 2, Februari 2011 